\begin{tabular}{r|r}
$\begin{array}{r}\text { Don Hanlon } \\
\begin{array}{r}\text { School Of Architecture and } \\
\text { Urban Planning }\end{array}\end{array}$ & $\begin{array}{r}\text { Research } \\
\text { Arches and Culture } \\
\text { University of Wisconsin - } \\
\text { Milwaukee } \\
\text { Abstract. Technological innovation is the driving force of our } \\
\text { civilization. Therefore, we assume all other civilizations would } \\
\text { exploit a technological advantage to the same degree that we } \\
\text { would. We forget, however, that technology is an aspect of } \\
\text { culture, and as with any other aspect of culture, it may be more or } \\
\text { less important to any given civilization. The history of the arch is } \\
\text { an interesting case in point. The arch is a structural device in } \\
\text { architecture that has distinct advantages over post-and-beam } \\
\text { construction. People have known how to build the arch and how } \\
\text { to use it since the third millennium B.C., but did not use it } \\
\text { because its form and meaning did not fit with other dimensions of } \\
\text { their respective cultures. }\end{array}$ \\
$\begin{aligned} \text { keywords: architecture, } \\
\text { culture, construction } \\
\text { technology, arch }\end{aligned}$
\end{tabular}

\title{
Introduction
}

In the last three hundred years, the mainstream of western architectural history and criticism depended on two methods of measuring value. The first, predominantly of the eighteenth and nineteenth centuries, was the Romantic appreciation of art. Its project was to categorize historical styles based on European aesthetic judgment. Aesthetic value, or Beauty, resided in that which was virtuous or truthful from a European perspective, so the architectural debates of the nineteenth century centered, to a great extent, on religious or moral virtues. For example, Ruskin contrasted what he claimed were the authentic European Christian virtues of the Gothic style against the decadent orientalism of Classical architecture. The second measure of architectural value emerged from industrialism in the late nineteenth and early twentieth centuries. Technological rationalism argued that Beauty resides in that which is the most direct, objective, and logical solution to a physical problem, using the most up-to-date materials and technologies available.

Art appreciation and technological rationalism have continued to be the dominant ways by which we judge the merits of architectural form in our own culture and we continue to project the same set of values onto those cultures which preceded us. However, these products of specific social, political, and economic conditions of early Modernism prevent us from understanding the motivations of architectural designers who built before the modern era. Ancient people did not create art and architecture for the aesthetic pleasure of modern people. To judge the merits of ancient architecture solely on aesthetic grounds is to presume that ancient architects did so as well and, moreover, shared our system of values. Likewise, technological rationalism presumes that ancient people judged the success or beauty of their architecture by values that arose from an equivalent of industrialism. If the architects who built the pyramid of Cheops in the third millennium BC had access to steel and concrete, would they have built the St.

Nexus Network Journal 8 (2006) 67-72

NEXUS NETWORK JOURNAL - VOL. 8, NO. 2, 200667 
Louis arch instead? Would the Greek architects, Ictinus and Calicrates, have built the Sears Tower instead of the Parthenon?

The role of the arch - and its derivative, the vault - in architectural history reveals a third way of understanding how values shape architecture. Though the arch can be understood aesthetically as a sculptural form and technologically as a structural form, it is first and foremost a cultural form because ancient people distinguished architecture from mere building not on the basis of aesthetics or technological ingenuity, but on the basis of cultural meaning. To illustrate this assertion, let us examine two architectural traditions, the Egyptian and the Greek. There is extensive evidence to show that both the Egyptians and the Greeks understood the arch as a structural device and had the technological sophistication to use it to full advantage, yet they avoided it or relegated it to minor, inconsequential applications because it did not fit into the web of meanings that dominated their respective cultures.

\section{The arch in Egypt}

In the earliest archaeological record of Egypt, we find depictions of small structures with curved roofs. The roofs were not arches or vaults, however. The walls and roofs of these houses were composed of lightweight bent wooden frames, or bundles of reeds, covered with woven mats or textiles. This was a simple device that exploited materials easily at hand. As the form of the common house became associated with the ruler and eventually with divine beings, it became a stylized pavilion. Since Egyptian civilization was profoundly conservative, the architectural forms that emerged at its inception persisted throughout its entire history, unchanged in form but varying in material. The small wooden house became the model for subterranean "houses" for the dead built of sun-dried brick. By the beginning of the Third Dynasty (ca. 2686 BC), the Egyptians were masters of brick construction, including the use of arches and vaults. However, their only application of this technology was in burial chambers below ground where brick was more durable than wood and where the lateral thrust of an arch or a vault was easily absorbed by the surrounding compacted earth. For example, the tombs at Reqâqnah and Bêt Khallâf are evidence of the Egyptians' understanding of the mechanics of the arch [Garstang 1904, 22]. These were true arches and vaults, composed either of standard bricks with a wedge-shaped infill of mud mortar or of specially shaped bricks that acted as voussoirs. Because of the Egyptian obsession with the continuity of form from life through death, these tombs were subterranean replicas in brick of the terrestrial wooden house, complete with curved roof [Smith 1968, 55].

The mortuary complex of Zoser at Saqqara was the first monumental stone architecture in history. Within the complex, a single example illustrates that the Egyptians understood the structural advantage of an arch at a very early date and knew how to construct it in stone. It is the small relieving arch, with cut stone

68 Donald L. Hanlon - Arches and Culture 
voussoirs, in the tomb of Hebset-Neferkara. However, this too is below ground. The Egyptians appear to have had no interest in using the structural advantages of the arch above ground. Nowhere do we find the light rhythmic effects produced by arcaded walls. Likewise, their use of vaults above ground was characteristically conservative, limited in almost all cases to small utilitarian structures, typified by the long, narrow storage cells in the Ramesseum (Nineteenth Dynasty) [Smith $1968,134]$. The technique of placing bricks to create these tunnel vaults is called laminated vaulting, by which masons laid brick courses at an angle against one end wall, each course bearing on its predecessor. This technique does not require timber centering and is still used, three millennia later, in rural Egypt. One of the rare uses of what appears to be a vault in a sacred space is in the Sanctuary of Osiris at Abydos (also of the Nineteenth Dynasty). It is not a true vault, however, but a corbelled one, in which horizontal courses of stone were carved into a curve [Smith $1968,169]$. The intention here was not to create a new kind of architectural space, but to create an interior space, in stone, reminiscent of an archaic house with a curved roof composed of bent reeds and matting.

Also at Saqqara, the elegantly curved roofs of the shrines facing the Heb-Set Court give the impression of vaults, but they are not. Their non-structural curved stone skins merely covered solid brick cores. Once again, the intention was to perpetuate an ancient tradition of architectural form, the sacred house, which conveyed a fundamental meaning in Egyptian culture: the fixed linkage of the present with the primordial past [Lauer 1976, 135]. These examples illustrate that brick and stone came into use in Egypt not to provide a new aesthetic, or to be explored and celebrated as technological innovations, but rather to preserve immutable architectural stereotypes in buildings of increasing scale and durability. The technological sophistication that the Egyptians brought to bear upon the construction of the pyramids - the cutting, transport, and setting of stones weighing many tons with great precision - clearly shows a level of ingenuity and invention that could have been devoted to solving the problems of lateral thrust produced by arches and vaults above ground. The same basic engineering that was used to construct simple round arches could have been turned to producing large, unified interior spaces spanned by vaults. To the contrary, the Egyptians showed no interest in this line of thought because these forms and spaces had no cultural relevance. Instead, Egyptian monumental architecture - such as the temples at Karnak, Deir el-Bahari, and Luxor - relied exclusively on a trabeated structure of columns and beams that replicated an ancient tradition of diminutive domestic structures in wood at a colossal scale in limestone.

\section{The arch in Greece}

The Greeks were among the greatest practitioners of masonry construction in the entire history of architecture. For example, their superb technique for constructing walls with cyclopean polygonal stones was exceeded only by the masons of the Incan Empire. However, the Greeks' craftsmanship was not matched 
by structural experimentation. Their use of the arch and the vault was highly conservative and examples before the Roman era are rare. This cannot be explained by ignorance, since they had extensive and prolonged contacts with Oriental cultures that used the arch extensively. The arch and the vault had been used in Western Asia for many centuries prior to the Greeks arrival, but these examples were composed of brick, a material in which the Greeks showed little interest [Lawrence 1983, 170]. The Greeks used the arch or vault of stone only in situations where the lateral thrust was easily counteracted by massive walls, as in fortifications, or by the earth in subterranean chambers. However, the Greeks' reticence to use the arch and the vault cannot be explained by a lack of technical knowledge or skill. The primary factor was cultural. Similar to the Egyptians, the Greeks established a formal language for their architecture at a very early date and never deviated from its rules. Their architecture was of a trabeated type, composed of columns and beams, originally of timber and later translated into stone. Every element and detail of the Classical canon of architecture that the Greeks used in their monumental temples constructed of stone, such as the Parthenon, has a direct correlation to a timber component in their archaic domestic buildings. It was for cultural reasons that the Greeks chose not to use any structural system other than a trabeated system in their major civic and religious buildings. Their urban form, the polis, was the basis of Greek identity and defined a group as a distinct racial entity with an unbroken historical and mythic connection to the origins of their civilization. Likewise, their ancestral architectural form was the megaron, a small dwelling composed of a more or less cubic interior volume, with a colonnaded porch, both protected by a single gable roof. This was the archetypal building from which the Greeks derived the designs for all of their civic and religious structures. Even their grandest and most elaborate buildings were variations on the theme of the simple megaron.

The Greek temple was foremost a symbol of the sanctuary, or shelter for a cult deity, a deity that protected and perpetuated the identity of a people. As a symbol for an immutable principle, its form could not change. Therefore, the entire architectural project of the Greek canon, extending over a millennium, was to only make incremental refinements to an established model. Furthermore, monumental Greek architecture was to be contemplated as sculpture in brilliant sunlight and in relation to its surrounding landscape; it was not dedicated to enclosing interior space. Therefore, the Greeks lacked an incentive to experiment with structural systems such as the arch, vault or dome that would have expanded or elaborated interior volumes.

\section{Conclusions}

The two Modernist methods of measuring value in architectural history - art appreciation and technological rationalism - do not help us to understand the ways in which people in preceding cultures thought. The archaeological plunder that we consider "art" had no artistic significance, in the Modern sense, to the people who

70 DONALD L. HANLON - Arches and Culture 
created it. Whether it was a small cult figure or a monumental building, it was a ritual object whose sole purpose was to preserve cultural meanings. These artifacts comprised a cultural landscape that fused myth, history, language, and social relations in a single form. Our contemporary aesthetic values can at best suggest a superficial parallel experience.

The application of technological rationalism reveals an even greater disassociation of ideas. The ideology of modern culture is technological innovation. Technology is the single greatest determinant of our well-being and of our self-image, both as individuals and as a civilization, because it shapes a set of values that determines for us the relevance of knowledge and experience. In our view, the advance of technology is inexorable and irresistible, so we assume that every technological advance must be exploited, regardless of the consequences. It is our mythology, the overarching religion of our age. In our daily lives, technology drives time, deconstructs space and creates it anew in strange and compelling forms. Anyone who resists is considered naïve, anachronistically Romantic, or off their medication. After all, is not the advance of technology a fact of life? It is inconceivable that entire civilizations would not only fail to exploit a technology that offers distinct advantages, but even worse, actively avoid it. However, the reason we feel this way is because we have forgotten that technology is a cultural phenomenon, and as such, it is susceptible to the forces of other dimensions of culture, such as language and myth. Each civilization uses a set of values to determine the relative importance of the many kinds of experiences that comprise their culture. We have placed technology at the pinnacle of our hierarchy of relevance, but other cultures have not. If we judge those civilizations by our set of values, we will never know them, and will probably simply dismiss them as ignorant and primitive. The civilizations of the Egyptians and the Greeks rejected an architectural technology that had obvious practical advantages because it failed to reinforce or elaborate the underlying forms of their respective cultures. They made a conscious choice to pursue meaning in the physical and mythic worlds as an integrated whole within the limits of familiar cultural patterns.

\section{Bibliography}

GARSTANG, John. 1904. Tombs of the Third Egyptian Dynasty at Reqâqnah and Bêt Khallâf (Westminster: Archibald Constable).

SMITH, Earl Baldwin. 1968. Egyptian Architecture as Cultural Expression (Watkins Glen: American Life Foundation).

LaUer, Jean-Philippe. 1976. Saqqara - The Royal Cemetary of Memphis (London: Thames \& Hudson).

LaWrenCE, A.W. 1983. Greek Architecture, 5 ed. (New Haven: Yale University Press). 


\section{About the author}

Don Hanlon is an architect and Professor, focusing on design, history, and theory. His research and writing has concentrated on cultural aspects of architecture and urban design, primarily in Islamic societies in Egypt, India, and Central Asia. His interest in cultural forces at work in the history of architecture has also included papers and lectures concerning the uses of architectural symbolism by Native Americans in their resistance to colonialism, and the origins and morphology of the American gas station. 